\title{
PENERAPAN AKAD SALAM DALAM TRANSAKSI JUAL BELI GABAH \\ (STUDI KASUS DI DESA BALEREJO KECAMATAN BALEREJO KABUPATEN MADIUN)
}

\author{
ERINA FATKUL FATIMAH \& ABD. HADI \\ e-mail: erinaadji.08@gmail.com
}

\begin{abstract}
ABSTRAK
Penelitian ini membahas tentang penerapan akad salam dalam jual beli gabah yang dilakukan oleh masyarakat di desa Balerejo kecamatan Balerejo kabupaten Madiun. Permasalahan yang hendak diteliti di sini dibatasi dengan beberapa persoalan berikut: (1) Bagaimana penerapan konsep akad salam dalam transaksi jual beli gabah oleh masyarakat desa Balerejo kecamatan Balerejo kabupaten Madiun? (2) Bagaimana tinjauan hukum Islam tentang pelaksanaan akad salam dalam transaksi jual beli gabah?

Penelitian ini adalah penelitian lapangan (field research) dimana penelitian dilakukan dengan cara mendatangi subjek dan objek penelitian yang ada di lokasi penelitian. Selain itu penelitian ini juga akan melihat pelaksanaan jual beli gabah dengan akad salam tersebut dari perspektif hukum Islam.

Hasil penelitian ini adalah: (1) Dari hasil penemuan penelitian yang penulis lakukan di desa Balerejo, penulis mendapati bahwa transaksi jual beli gabah di lokasi penelitian dapat dikatakan sebagai transaksi jual beli salam karena adanya persamaan-persamaan fundamental dengan konsep akad salam seperti persamaan dalam masalah dasar hukum, akad transaksi, objek akad, pembayaran, dan serah terima objek akad. (2) Pelaksanaan jual beli gabah tersebut juga relevan dan sejalan dengan konsep kemaslahatan dan keadilan apabila ditinjau dari perspektif tujuantujuan universal syariah Islam.
\end{abstract}

Kata kunci: Akad, Jual beli, Salam, Gabah, Hukum Islam.

\section{PENDAHULUAN}

Jual beli merupakan aktivitas tukar untuk saling memenuhi dimana manusia melakukan transaksi kebutuhan hidup di antara sesama. tukar-menukar barang dengan alat Pengertian lainnya tentang jual beli 
(bay') adalah pertukaran harta (mal) dengan harta melalui sistem yang menggunakan cara tertentu. Sistem pertukaran harta dengan harta dalam konteks harta yang memiliki manfaat serta terdapat kecenderungan manusia untuk menggunakannya. Adapun yang dimaksud dengan cara tertentu adalah bahwa jual beli itu menggunakan ungkapan (sighat, ijab dan qabul). ${ }^{1}$

Dalam jual beli yang dihalalkan, bentuk dan keberadaan benda yang menjadi objek transaksi haruslah jelas. Karena itu tidak dibenarkan melakukan transaksi jual beli atas barang yang tidak jelas bentuk dan keberadaannya seperti jual beli hewan yang masih berada dalam bibit jantan (al-mulaqih), jual beli hewan yang masih berada dalam perut induknya (mudhamin), jual beli tanah yang luasnya sejauh lemparan batu (alhushah), jual beli buah-buahan yang masih berada di tangkainya dan belum layak dimakan (al-muhaqalah), serta

\footnotetext{
${ }^{1}$ Ismail Nawawi, Fikih Muamalah Klasik dan Kontemporer, (Bogor: Ghalia Indonesia, 2012), hlm. 75.
}

jual beli atas barang yang belum berwujud. $^{2}$

Salah satu fenomena jual beli yang saat ini sering dilakukan oleh masyarakat adalah jual beli dengan model pesanan. Jual beli pesanan dalam Islam dibagi ke dalam dua jenis yaitu jual beli salam dan jual beli istishna'. Kedua jenis jual beli ini merupakan jual beli suatu barang atau komoditas yang mana barang yang diperjual-belikan wujudnya belum ada pada penjual. Meskipun jual beli salam dan jual beli istishna' merupakan jual beli pesanan, namun terdapat perbedaan yang signifikan antara kedua jenis jual beli tersebut.

Jual beli salam adalah jual beli suatu barang atau benda yang tidak ada ditempat terjadinya akad, dimana pembeliannya dilakukan dengan cara memesan barangnya terlebih dahulu dengan mengetahui kriteria-kriteria barang yang ingin dibeli. Jual beli salam atau jual beli salaf diartikan dengan jual beli dimana harga

\footnotetext{
${ }^{2}$ Hasan Saleh, Kajian fiqh Nabawi dan Fiqh Kontemporer, (Jakarta: Raja Grafindo Persada, 2008), hlm.383-385.
} 
dibayarkan dimuka sedangkan barang dengan kriteria tertentu akan diserahkan pada waktu tertentu yang disepakati. Meskipun demikian, konsep jual beli salam sebenarnya tidak sesederhana yang didefinisikan. Terdapat banyak syarat dalam fiqh yang ditetapkan oleh para ulama yang harus dipenuhi agar jual beli salam tersebut diakui kehalalannya. Misalnya; (1) Pembayaran harus dilakukan secara kontan, baik dengan emas, perak, atau logam-logam lainnya agar hal-hal ribawi tidak diperjualbelikan dengan sejenisnya dalam masa penundaan penyerahan barangnya, (2) Komoditi yang diperjual-belikan harus dengan sifatsifat yang jelas, misalnya dengan menyebut jenis dan ukurannya, agar tidak terjadi konflik antara penjual dan pembeli pada akhirnya; (3) Waktu penyerahan barangnya harus ditentukan, misalnya beberapa hari atau bulan yang akan datang; serta (4) Penyerahan uang dilakukan di satu majelis. Model jual beli semacam ini sebenarnya tidak sesuai dengan syarat kehalalan jual beli sebagaimana yang dibolehkan dalam Islam. Namun karena adanya tuntutan rasa keadilan, kemaslahatan dan sangat dibutuhkan oleh masyarakat, maka berdasarkan metode istihsan $^{3}$ jual beli salam tersebut diperbolehkan. Karena adanya rasa keadilan dan kebutuhan terhadap model jual beli semacam ini maka para ulama memperbolehkan dengan syarat-syarat tertentu. Hal ini sejalan dengan prinsip syariat Islam sendiri

\footnotetext{
${ }^{3}$ Secara etimologis istihsan diartikan sebagai "meminta berbuat kebaikan, yakni menghitung-hitung sesuatu dan menganggapnya kebaikan." Menurut istilah ulama ushul, istihsan adalah semua hal yang dianggap baik oleh mujtahid menurut akalnya. Ibnu Qudamah al-Hanbali berkata "Istihsan adalah suatu keadilan terhadap hukum dan pandangannya karena adanya dalil tertentu dari al-Qur'an dan Sunnah." Abu Ishaq alSyatibi berkata "Istihsan adalah pengambilan suatu kemaslahatan yang bersifat juz'i dalam menanggapi dalil yangbersifat global." Hasan al-Khurkhi al-Hanafi mendefinisikan istihsan sebagai "Perbuatan adil terhadap suatu permasalahan hukum dengan memandang hukum yang lain karena adnya suatu yang lebih kuat yang membutuhkan keadilan." Adapun Muhammad Abu Zahrah dan sebagian ulama ushul mendefinisikan istihsan sebagai "Perbuatan adil dalam hukum yang menggunakan dalil adat untuk kemaslahatan manusia." Istihsan adalah metode ijtihad yang diakui oleh mujtahid lain dan ditolak oleh mujtahid yang lain pula. Misalnya mazhab Hanafi, Maliki dan Hnbali menerima istihsan sbagai metode ijtihad, sedangkan mazhab Shafi'i menolaknya. Lihat Rachmad Syafe'i, Ilmu Ushul Fiqih, (Bandung: Pustaka Setia, 1999), hlm.111-112.
} 
yang memeritahkan umatnya untuk memberikan kemudahan dan tidak menyulitkan, serta memelihara keadilan dan kemaslahatan.

Di antara masyarakat yang mempraktikkan jual beli dengan cara salam adalah masyarakat desa Balerejo kecamatan Balerejo kabupaten Madiun. Transaksi jual beli dengan model salam atau pesanan seringkali ditemukan dalam masyarakat desa Balerejo terhadap komoditi gabah. Lebih-lebih dalam waktu satu bulan sebelum datangnya masa panen, jual beli gabah di desa Balerejo ini biasanya sudah mulai marak dilakukan dengan model pesanan, yakni pembeli menawar bulir-bulir padi yang masih berada di sawah-sawah warga dan sebenarnya belum siap untuk dipanen langsung kepada pemiliknya dengan sejumlah harga tertentu. Apabila pemilik tanaman padi atau petani gabah tersebut menyepakati harga yang ditawarkan, maka pembeli (tengkulak) segera membayar sejumlah harga yang telah disepakati, sedangkan bulir-bulir padi atau gabah yang telah dibeli tetap dibiarkan berada di sawah hingga siap untuk diketam (dipanen).

Sebagian dari pembeli (tengkulak) gabah yang tidak terlalu memiliki banyak modal biasanya ada pula yang membeli gabah setelah diketam meskipun akad pertama telah dilakukan jauh hari sebelum datangnya masa panen, kemudian gabah yang sudah dibeli sudah berada di karungkarung yang tertumpuk di pinggiran sawah penduduk, kemudian pembeli gabah tersebut menjualnya kepada pengepul gabah. Setelah mendapatkan uang, pembeli tersebut kembali mendatangi pemilik gabah (petani padi) untuk membayar sejumlah uang yang disepakati sebagai harga gabah yang telah dibeli tersebut. Kemudian gabah-gabah yang telah dibeli baru di ambil dan diangkut menggunakan truk yang disediakan oleh pembeli gabah tersebut.

Penelitian ini adalah penelitian lapangan (field research) dimana penelitian dilakukan dengan cara mendatangi subjek dan objek penelitian yang ada di lokasi penelitian. Penelitian ini juga termasuk 
penelitian hukum normatif, yakni suatu jenis penelitian yang bertujuan untuk mengetahui ada tidaknya suatu aturan hukum yang sesuai dengan norma hukum, atau ada tidaknya kesesuaian suatu tindakan hukum dengan norma atau prinsip hukum. ${ }^{4}$ Penelitian ini dimaksudkan untuk memeperoleh informasi data secara detail tentang proses transaksi jual beli gabah di desa Balerejo Kecamatan Balerejo Kabupaten Madiun dimana penulis hendak melihat permasalahan tersebut dari sudut pandang teori akad salam dalam hukum Islam.

Pendekatan yang digunakan dalam penelitian ini adalah pendekatan studi kasus, yakni suatu studi terhadap kasus tertentu dari berbagai aspek hukum. ${ }^{5}$ Pendekatan kasus juga dapat dipahami sebagai suatu penelitian yang bertujuan secara khusus menjelaskan dan memahami objek yang ditelitinya secara khusus sebagai suatu kasus pendekatan, kasus penulis gunakan

${ }^{4}$ Peter Mahmud Marzuki, Penelitian Hukum, (Jakarta: Kencana, 2016), hlm. 47.

${ }^{5}$ Ibid, hlm. 134. untuk memahami subjek dan objek penelitian secara kasuistik. Kemudian melalui pendekatan ini penulis akan melakukan interpretasi hukum berdasarkan korelasi yang penulis temukan antara tindakan subjek hukum dengan teori hukumnya. 


\section{PEMBAHASAN}

\section{Penerapan Akad Salam Dalam Transaksi Jual Beli Gabah di \\ Desa Balerejo Kecamatan \\ Balerejo Kabupaten Madiun}

Berdasarkan data yang penulis dapatkan dari responden, akad atau transaksi jual beli gabah biasanya dilakukan di sawah dimana gabah belum dipanen dan masih berada di tangkainya, dan kondisi gabah dalam kondisi masih sangat muda dan belum siap untuk dipanen. Adapun jual beli gabah ini umumnya dilakukan dengan model tebasan, yakni penjual bersepakat dengan pembeli gabah untuk melakukan jual beli gabah tanpa ditimbang per kilogram atau per kwintalnya, tetapi gabah dibeli secara keseluruhan, yakni satu petak sawah dengan harga yang disepakati.

Fenomena jual beli gabah dengan cara tebasan tersebut sebenarnya sudah lazim terjadi hampir di banyak tempat di pedesaan dan daerah pedalaman yang mana sumber pencaharian mereka adalah dari hasil pertanian. Jadi dapat dikatakan bahwa model jual beli dengan cara tebasan merupakan adat yang telah terjadi selama berpuluh-puluh tahun dan masih dilakukan oleh masyarakat pertanian hingga kini. Penulis sendiri telah lama mengenal sistem jual beli dengan cara tebasan ini dari masa kecil hingga sekarang dan masih terus berlangsung. Biasanya sistem jual beli sebagaimana tersebut tidak terbatas hanya pada masalah jual beli gabah saja, tetapi untuk berbagai produk hasil pertanian dan perkebunan. Demikian pula terhadap produk pertanian, tidak hanya gabah yang dijual dengan sistem tebasan, melainkan beberapa produk hasil pertanian lainnya seperti jagung, singkong, tembakau dan lain sebagainya.

di desa Balerejo, penjualan gabah dengan sistem tebasan merupakan hal yang lumrah terjadi dan hampir semua petani dan pedagang melakukan transaksi jual beli gabah dengan cara tersebut. Akad jual beli gabah dilakukan di tempat tinggal tengkulak atau calon pembeli gabah dengan cara mendatangi tengkulak atau pengusaha gabah selaku pembeli. Kebiasaan yang ia lakukan adalah 
menawarkan gabah miliknya di tempat tinggal tengkulak menjelang waktu panen untuk dilihat atau disurvey oleh tengkulak atau calon pembeli sebelum ditentukan harganya. Adapun salah seorang petani yang juga menjual gabahnya di tengkulak lokal, biasanya pada waktu mendekati musim panen beberapa calon pembeli mendatangi rumahnya untuk membeli gabahnya sebelum dipanen. Dan akad jual belipun dilakukan dirumahnya, jika keduanya sepakat dengan harganya maka gabah pun dijual dan jika tidak ia menunggu kedatangan calon pembeli lainnya di rumahnya.

Pemberian uang lebih awal sebelum barang diterima atau dipanen sebagai harga gabah yang dibeli sesuai yang disepakati biasa dilakukan oleh kebanyakan pembeli gabah di lokasi penelitian. Hal tersebut dilakukan karena mereka khawatir petani yang memiliki gabah akan menjual gabahgabah mereka kepada pembeli yang lain yang berani membeli dengan harga yang lebih mahal. Karena saat ini ada banyak sekali persaingan para tengkulak gabah yang tidak hanya antar tetangga atau antar dusun, tetapi antar desa dan bahkan antar kecamatan.

Mereka (para tenngkulak/ pengusaha gabah) tidak pernah melakukan pembelian gabah setelah gabah-gabah diketam, karena tidak menjadi kebiasaan bagi masyarakat menjual gabah setelah diketam atau dipanen. Berdasarkan data yang penulis dapatkan di lapangan, secara umum setelah transaksi jual beli gabah menghasilkan kesepakatan, beban mengambil gabah atau mengetam gabah dari sawah untuk kemudian dikirim ke lokasi atau gudang milik pembeli seluruhnya menjadi tanggungan pembeli. Jadi penjual dalam akad jual beli gabah menerima harga bersih dan tidak dikenai biaya pengetaman atau pengiriman. Selama penelitian ini dilakukan, penulis menemukan terdapat beberapa kasus dalam masalah pembayaran transaksi jual beli gabah di desa Balerejo sebagai berikut:

(1) Pembayaran diberikan secara cash sebelum gabah diketam oleh pembeli. 
(2) Pembayaran diberikan separuh di awal dan separuh lagi setelah gabah diketam dan dikirim.

Dalam beberapa kasus penulis menjumpai dimana uang harga penjualan gabah yang diberikan di awal tersebut hanya diberikan separuh oleh pembeli, dan sisanya setelah gabah berhasil dipanen dan diantarkan ke tempat yang diminta oleh pembeli, tentunya dengan biaya penuh dari pembeli tersebut. Hal ini dialami oleh Imam Pairin dimana ia menjual gabahnya kepada tengkulak gabah yang bernama Andik. Hal yang sama juga dialami oleh Sunarno yang menjual gabahnya kepada Anik Sumaryani. Menurut pengakuan kedua tengkulak tersebut (yaitu Andik dan Anik Sumaryani) hal seperti ini terjadi karena keduanya tidak memiliki modal yang memadai untuk membayar harga gabah secara cash atau kontan. Tetapi apabila harga gabah yang mereka beli diberikan di belakang, mereka takut penjualnya akan beralih kepada pembeli yang lain, karenanya sebagai uang panjer (semacam uang DP) mereka membayar separuh harga dulu, baru setelah gabah dijual kepada tengkulak yang lebih tinggi dan mendapat uang, mereka lakukan pelunasan kepada pemilik gabah atau petani. ${ }^{6}$

Ketika penulis bertanya kepada Imam Pairin dan Sunarno kenapa mereka bersedia dibayar dengan cara demikian, jawaban mereka berbeda tetapi sama esensinya, yaitu karena mereka sepakat dengan harganya, belum ada kebutuhan yang mendesak, dan adanya rasa kasihan kepada pembeli karena mereka bukan pembeli yang kaya, tetapi sama-sama warga desa yang berusaha mencari nafkah. ${ }^{7}$ Demikian jawaban yang penulis peroleh dari dua petani tersebut.

Namun demikian kebanyakan pelaksanaan pembayaran dalam jual beli gabah di desa Balerejo dilakukan di awal yakni pada waktu akad terjadi, sebelum pembeli menerima gabah yang ia beli.

\footnotetext{
${ }^{6}$ Hasil wawancara dengan tengkulak gabah bernama Andik dan Anik Sumaryani pada tanggal 26 Mei 2018.

${ }^{7}$ Hasil wawancara dengan Imam Pairin dan
Sunarno pada tanggal 26 Mei 2018 .
} 
(3) Pembayaran diberikan di akhir, yakni setelah gabah diketam dan dikirim ke tempat pembeli, baru kemudian penjual menerima uang sejumlah harga gabah yang disepakati bersama. Model yang terakhir ini tidak termasuk dalam kajian penelitian ini, karena berbeda dengan konsep akad dalam jual beli salam. Selain itu model pembayaran yang terakhir ini jarang terjadi di lokasi penelitian, kecuali ketika hasil panen benar-benar jelek, karena yang membutuhkan uang adalah petani atau penjual gabah, sehingga tengkulak berani membayar di belakang.

Mengenai prosesi penyerahan gabah dalam transaksi jual beli gabah di desa Belerejo dari penjual kepada pembeli, dapat diuraikan sebagai berikut:

(1) Penyerahan gabah secara lisan.

Penyerahan gabah secara lisan sebenarnya dilakukan oleh penjual ketika akad transaksi berlangsung. Adakalanya penyerahan tersebut diucapkan secara jelas, namun kebanyakan penyerahan tidak diucapkan secara jelas. Misalnya ketika penjual telah setuju dengan harga yang diberikan oleh pembeli gabah, penjual hanya berkata "Yo wes ndang gowo (Ya sudah silahkan dibawa)." " Maksudnya adalah pembeli diperkenankan memanen gabah miliknya kapanpun pembeli mau setelah akad jual beli mencapai kesepakatan.

(2) Penyerahan gabah secara tindakan.

Penyerahan gabah hakekatnya baru dilakukan setelah gabah yang masih berada ditangkainya sebagai objek jual beli tersebut diketam atau dipanen oleh si penjual sendiri (bukan oleh petani pemilik gabah). Biasanya yang bertanggung jawab mengetam gabah setelah tercapai kesepakatan jual beli adalah penjual sendiri, sehingga dapat dikatakan bahwa penyerahan objek jual beli gabah adalah sama dengan waktu pengambilan gabah dari sawah oleh si pembeli sendiri. Adapun biaya pengetaman seperti upah buruh,

\footnotetext{
8 Kalimat ini diambil dari observasi akad transaksi yang dilakukan oleh Suprayitno sebagai petani penjual gabah kepada Karno sebagai tengkulak atau pembeli gabah, pada tanggal 27 Mei 2018.
} 
konsumsi, dan transportasi seluruhnya menjadi tanggungan pembeli gabah. Hal seperti ini sudah lazim terjadi di lokasi penelitian, yakni di desa Balerejo dan di desa-desa lainnya sekecamatan Balerejo kabupaten Madiun.

Dalam kegiatan transaksi jual beli gabah di desa Balerejo, penulis sejauh penelitian ini tidak menemukan penyebutan lokasi penyerahan gabah baik oleh penjual maupun pembeli. Jadi kedua belah pihak tidak pernah menyinggung tentang lokasi penyerahan gabah, yang jelas ketika gabah sudah dibeli, pengambilan gabah sudah menjadi urusan pembeli. Berdasarkan pengamatan penulis di lapangan, penjual dalam hal ini tidak pernah diminta oleh pembeli manapun untuk mengantar atau mengirim gabah yang sudah di beli di suatu tempat tertentu.

\section{Tinjauan Hukum Islam Tentang} Pelaksanaan Akad Salam Dalam Transaksi Jual Beli Gabah Pelaksanaan Akad Salam Dalam Transaksi Jual Beli Gabah di desa Balerejo kecamatan Balerejo kabupaten Balerejo tersebut apabila ditinjau dari perspektif hukum Islam dapat dijelaskan sebagai berikut:

\section{Perspektif Ushul Fiqh}

Dalam kaitannya dengan teori ushul fiqh, pelaksanaan akad salam dalam transaksi jual beli gabah dapat ditemukan relevansinya dengan beberapa teori istihsan, istishab dan 'urf.

\section{a. Istihsan}

Dilihat dari sisi etimologis, istihsan artinya mengikuti sesuatu yang menurut analisis nalar adalah baik (fisik maupun nilainya). Kata ini kemudian digunakan untuk membentuk suatu pengertian baru yang menggambarkan suatu konsep penalaran dalam rangka penggunaan rasio secara lebih luas untuk menggali dan menemukan hukum suatu peristiwa yang tidak ditetapkan hukumnya dalam sumber syariah yang tersurat atau sumber hukum lainnya yang disamakan. ${ }^{9}$

\footnotetext{
${ }^{9}$ Ali Yafie, Konsep-konsep Istihsan, Istislah dan Maslahah al-Ammah, dalam Kontekstualisasi Doktrin Agama Dalam
} 


\section{b. Istishab}

Istishab adalah melestarikan suatu ketentuan hukum yang telah ada pada masa lalu, hingga ada dalil yang mengubahnya. 10 Lebih jelasnya, istishab yakni menetapkan sesuatu menurut keadaan sebelumnya sampai terdapat dalil-dalil yang menunjukkan perubahan keadaan, atau menjadikan hukum yang telah ditetapkan pada masa lampau secara kekal menurut keadaannya sampai terdapat dalil yang menunjukkan perubahannya.

\section{c. Urf}

'Urf adalah sesuatu yang telah dibiasakan oleh manusia dan mereka menjalaninya dalam berbagai aspek kehidupan. ${ }^{11}$ Lebih jelasnya, 'urf adalah suatu keadaan, ucapan, perbuatan, atau ketentuan yang telah dikenal manusia dan telah menjadi

Sejarah,( Jakarta: Paramadina, 1994), hlm. 364.

${ }^{10}$ Abdul Wahab Khalaf, Mashadir at-Tasyri' al-Islami fi ma la Nash fih, Kuwait: Dar alQalam, 1402 H, h. 151.

${ }^{11}$ Lihat Abdul Aziz al-Khayyath, Nazhariyah al-'Urf, Amman: Maktabah al-Aqsha, 1397 H, h. 24 . tradisi untuk melaksanakannya atau meninggalkannya. Di kalangan masyarakat 'urf ini sering disebut sebagai adat. Mayoritas ulama menerima 'urf sebagai dalil hukum, tetapi berbeda pendapat dalam menetapkannya sebagai dalil hukum yang mandiri. 


\section{KESIMPULAN}

Mengenai penerapan akad salam dalam transaksi jual beli gabah di desa Balerejo kecamatan Balerejo kabupaten Madiun, dapat disimpulkan sebagai berikut:

Dari hasil penemuan penelitian yang penulis lakukan di desa Balerejo, penulis mendapati bahwa transaksi jual beli gabah di desa Balerejo kecamatan Balerejo kabupaten Madiun dapat dikatakan sebagai transaksi jual beli yang menggunakan konsep akad salam karena adanya persamaanpersamaan fundamental dengan konsep akad salam seperti persamaan dalam masalah dasar hukum, akad transaksi, objek akad, pembayaran, dan serah terima objek akad. Meskipun masyarakat di desa Balerejo tidak merujuk secara langsung konsep jual beli salam dalam fiqh muamalah, tetapi praktek jual beli gabah yang mereka lakukan sebenarnya adalah praktek jual beli salam menurut penulis. Penulis juga menemukan beberapa perbedaan pelaksanaan jual beli gabah di desa Balerejo dengan konsep akad salam, yaitu mengenai objek salam dimana pada akad salam objek akadnya belum ada, sedangkan dalam jual beli gabah objek akadnya sudah ada, hanya saja penyerahannya kepada pembeli tergantung kemauan pembeli. Perbedaan lainnya adalah tentang penyerahan objek akad, dalam akad salam penyerahan dilakukan oleh penjual, sedangkan dalam jual beli gabah tidak ada penyerahan, yang ada adalah pengambilan objek akad oleh pembeli dengan seluruh biaya pengambilan ditanggung oleh pembeli. Apabila dilihat dari sisi keabsahannya, penulis berpendapat bahwa jual beli gabah yang dipraktekkan oleh warga desa Balerejo kecamatan Balerejo kabupaten Madiun adalah sah dari sisi hukum syar'i. hal tersebut karena menurut pandangan penulis, suatu adat kebiasaan yang terjadi berulang-ulang dan terus dilakukan dari dahulu hingga saat ini karena adanya kemaslahatan, serta tidak bertentangan dengan prinsipprinsip syariah Islam, maka adat tersebut dapat diambil sebagai hukum yang dalam istilah ilmu ushul fiqh disebut sebagai 'urf. Penggunaan adat 
sebagai hukum telah diakui keharaman jual beli gabah dengan kehujjahannya oleh jumhur ulama akad salam) dan 'urf (karena jual beli ushul fiqh. Karena itu jual beli gabah dengan cara salam di desa tersebut dengan cara tebasan dan dilakukan dengan sistem salam seperti yang terjadi di desa Balerejo tersebut hukumnya sah karena merupakan kebutuhan masyarakat banyak yang dapat mewujudkan kemaslahatan dalam kehidupan mereka.

Ditinjau dari perspektif hukum Islam, pelaksanaan akad salam dalam transaksi jual beli gabah di desa Balerejo kecamatan Balerejo kabupaten Balerejo sejalan dengan konsep istihsan (karena konsep salam sendiri merupakan produk dari metode istihsan), istishab (karena tidak ditemukan dalil baik dalam al-Qur'an maupun hadis yang menyatakan sudah berlangsung sangat lama dan adat tersebut tidak menyelisihi sdalildalil syariah) dalam teori ushul fiqh. Pelaksanaan jual beli gabah tersebut juga relevan dan sejalan dengan konsep kemaslahatan (karena jual beli dengan sostem tersebut sangat dibutuhkan dan terbukti memudahkan urusan masyarakat di desa tersebut) dan keadilan (karena berdasarkan hasil penelitian tidak ditemukan adanya unsur penipuan, gharar maupun paksaan) apabila ditinjau dari perspektif tujuan-tujuan universal syariah Islam sebagaimana yang dikemukakan oleh Muhammad Thahir Ibnu Asyur.

\section{DAFTAR PUSTAKA}

'Âshûr, Muhammad Thâhir Ibn, Maqâshid al-Sharî'ah al-Islâmiyyah, Tunis: AlShirkah al-Tuniziyyah li al-tawzi'.

Al-Ghazali, Muhammad Abu Hamid, Al-Musytasyfa, Beirut: Dâr al-Kitâb alIlmiyyah, t.th.

Al-Jazairi, Abu Bakar, Minhajul Muslimin, Beirut: Dar al-Fikr, 2003.

Al-Khayyath, Abdul Aziz, Nazhariyah al- 'Urf, Amman: Maktabah al-Aqsha, 1397 H. 
Al-Zuhaili, Wahbah, Fiqh al-Islam wa Adillatuh, juz 4, Damaskus: Dar al-Fikr, tth. Al-Zuhaili, Wahbah, Ushul al-Fiqh al-Islami, Beirut: Dar al-Fikr, 1406 H.

Azzam, Abdul Aziz Muhammad, Fiqh Muamalat, Jakarta : Amzah, 2010.

Basyir, Ahmad Azhar, Asas-Asas Hukum Muamalat, Yogyakarta: UII Pres, 1982.

Ghazaly, Abdul Rahman, Fiqh Muamalat, Jakarta : Kencana, 2010.

Harun, Nasrun, Ensiklopedi Hukum Islam, Jakarta: PT Ihktiar Baru Van Hoeve, 2003.

Hasan, Husein Hamid Nazariyat al-Maslahah fi al-Fiqh al-Islami, Beirut: Dar anNahdhah al-Arabiyah, 1971.

Hasan, Saleh, Kajian fiqh Nabawi dan Fiqh Kontemporer, Jakarta: Raja Grafindo Persada, 2008.

Hasby Ash-Shiddieqy, Pengantar Fiqh Muamalah, Jakarta : Bulan Bintang, 1997.

J. Feinberg, Philosophy of Law, California: Wadsworth Publisher Company Inc, 1975.

J. Rawis, A Theory of Justice, Massachusetts: Harvard Universit Press, 1971.

Khalaf, Abdul Wahab, Mashadir at-Tasyri' fi ma la Nassa fih, Kuwait: Dar al-Qalam, 1972.

Lexi J. Moleong, Metodologi Penelitian Kualitatif, Bandung: Rosdakarya, 2007.

Madjid, Nurcholis, Islam Doktrin dan Peradaban, sebuah Telaah Kritis Tentang Masalah Keimaanan, Jakarta: Yayasan Wakaf Paramadina , 1992.

Marzuki, Peter Mahmud, Penelitian Hukum, Jakarta: Kencana, 2016.

Muslehuddin, Muhammad, Philosophy of Islamic Law and the Orientalist, New Delhi: Taj Company, 1986.

Muslih, Ahmad Wardi, Fiqh Muamalah, Jakarta: Amzah, 2013.

Nawawi, Ismail Fikih Muamalah Klasik dan Kontemporer, Bogor: Ghalia Indonesia, 2012.

Sabiq, Sayid, Fiqh al-Sunnah, juz 3, Beirut Dar al-Fikr, 1981.

Suhendi, Hendi, Fiqh Muamalah, Jakarta: Raja Grafindo Persada, 2008.

Syafe'i, Rachmad, Ilmu Ushul Fiqih, Bandung: Pustaka Setia, 1999. 
Yafie, Ali, Konsep-konsep Istihsan, Istislah dan Maslahah al-Ammah, dalam Kontekstualisasi Doktrin Agama Dalam Sejarah, Jakarta: Paramadina, 1994.

Zahrah, Muhamamd Abu, Al-Milkiyah wa Nazhariyah al-Aqh di al-Syari'ah alIslamiyah, Beirut: Dar al-Fikr, 1976.

Zaid, Musthafa, Shar'hu al-Arba'in al-Nawawiyah: Mulhaq bi al-Risâlah alMaslahah fî Tashrî' al-Islâmî Najmuddîn al-Thûfî, t.tp: Dâr ak-Fî kr al-Arâbî, t.th. 